Georgia State University

ScholarWorks @ Georgia State University

Middle-Secondary Education and Instructional Department of Middle-Secondary Education and Technology Faculty Publications Instructional Technology (no new uploads as of Jan. 2015)

2009

\title{
The Social Studies Curriculum in Atlanta Public Schools During the Desegregation Era
}

Chara Haeussler Bohan

Georgia State University, cbohan@gsu.edu

Patricia Randolph

Follow this and additional works at: https://scholarworks.gsu.edu/msit_facpub

Part of the Elementary and Middle and Secondary Education Administration Commons, Instructional Media Design Commons, Junior High, Intermediate, Middle School Education and Teaching Commons, and the Secondary Education and Teaching Commons

\section{Recommended Citation}

Bohan, C. H. \& Randolph, P. (2009). The social studies curriculum in Atlanta Public Schools during the desegregation era. Theory and Research in Social Education, 37(4), 543-569. DOI: 10.1080/

00933104.2009.10473410

This Article is brought to you for free and open access by the Department of Middle-Secondary Education and Instructional Technology (no new uploads as of Jan. 2015) at ScholarWorks @ Georgia State University. It has been accepted for inclusion in Middle-Secondary Education and Instructional Technology Faculty Publications by an authorized administrator of ScholarWorks @ Georgia State University. For more information, please contact scholarworks@gsu.edu. 


\title{
Atlanta's Desegregation Era Social Studies Curriculum: An Examination of Georgia History Textbooks
}

\author{
Chara Haeussler Bohan and Patricia Randolph \\ Georgia State University \\ Do not cite without author's written permission
}

In the context of the desegregation of Atlanta Public Schools (APS), we sought to explore issues of race and the social studies curriculum during the 1970s and 1980s in Atlanta, GA. According to population measure of residence per square mile, Atlanta is one of the largest cities in the Southeast region of the United States. This time period marked the tenure of Dr. Alonzo Crim, the first African American APS Superintendent of Schools, and also witnessed the end of a fifteen-year court battle over school desegregation in the city schools. Issues of race were of central concern during desegregation. Thus, 1973 was the start of a new era and we wondered how the social studies curriculum was impacted. Were there changes in the way social studies was taught and learned given the desegregation history that actually happened in the schools? As an extension of prior research, ${ }^{1}$ where we searched through archival materials, conducted interviews with students, teachers, and administrators, and examined court records, we furthered this larger investigation into the social studies curriculum by initiating a new examination of the Georgia history textbooks that were used in Georgia's classrooms. The textbooks reveal, like the interviews and archival materials, a story of resistance to progressive change in the social studies curriculum, although we found administrators and teachers who initiated some guarded attempts to broaden teaching and learning.

Setting the Stage: The Impact of National and State Social Studies Curriculum Movements 
In the post-Sputnik era, the federal government poured considerable money into education. Indeed, Urban and Wagoner report that the most significant consequence of Sputnik was not the space race or the attention to academic studies, but "the impetus it gave to federal financing of public education." ${ }^{2}$ By the late 1960s, social studies education was a beneficiary of federal funding. Historically, social studies education has faced division between supporters of a discipline-centered approach and advocates of inquiry-based, social education methods. ${ }^{3}$ These national level debates over the "new social studies" curriculum were experienced inside APS, as well. ${ }^{4}$ During Dr. Crim's fifteen-year leadership, even the name of the social studies curriculum changed. The 1983 APS social studies curriculum guide was divided into two sections: Social Sciences and Social Studies. In 1975, Jeanette B. Moon's position was Coordinator of the Social Sciences. ${ }^{5}$ By the 1980s, the Atlanta Public School Georgia History Curriculum for eighth graders was referred to as Social Studies. Along with the distinction of the curriculum changing names, even more controversy developed over how the subject should be taught.

\section{MACOS in Atlanta}

When Dr. Crim became APS Superintendent, there were more than one hundred "new social studies" curricula developed nationwide. ${ }^{6}$ One of the most well known of the "new social studies" curricula was MACOS (Man: A Course of Study), and Atlanta education administrators considered the curriculum for their social studies courses. MACOS was based on theories of Jerome S. Bruner. Bruner created a "spiral curriculum" and MACOS focused on what made

human beings human. ${ }^{7}$ The curriculum did not emphasize specific social studies content, but emphasized the process of the discovery and as such, fostered inquiry-based knowledge. 
The MACOS curriculum included the study of different cultures and helped students broadly understand the human condition. Bruner (1996) believed that "learning and thinking are always situated in a cultural setting and always dependent upon the utilization of cultural resources." ${ }^{8}$ MACOS afforded students the opportunity to experience a more culturally relevant social studies curriculum. MACOS did not have a Eurocentric emphasis but purposely examined non-Western cultures. MACOS encouraged students to ask questions, discuss alternatives, and reach conclusions based upon evidence and argument. One of the units of study, for example, focused on the practices of the Netsilik Eskimos, whose cultural practices were markedly different from most Western cultures.

Yet many local educators viewed MACOS materials as inherently controversial. ${ }^{9}$ The curriculum fostered the questioning of life and morality that many conservatives found unacceptable. Historically, Georgia has had a considerably large conservative, Baptist population, as one in five Georgians were Southern Baptists in $1970 .{ }^{10}$ Thus, most Georgia conservatives ardently opposed the MACOS curriculum. Although the MACOS curriculum gained negative attention in the local newspapers, it also enjoyed some limited support from the Atlanta community. ${ }^{11}$ Ultimately, the conservative local opposition, however, squelched the possibility of adopting MACOS. MACOS represented an opportunity to implement an innovative curriculum that promoted a broad examination of culture, and which may have been more relevant for Atlanta's African American students. Instead, as one Northside High School graduate from the mid-seventies noted, most of her social studies classes comprised the traditional narrative of dead, White men. ${ }^{12}$

By the early 1970s, "new social studies" projects had grown in popularity, but many critics arose, as well. For example, Edwin Fenton authored a textbook series that also promoted 
an inquiry approach in social studies education. ${ }^{13}$ Fenton, a respected academic from Carnegie Institute of Technology, nonetheless, became a target of criticism. The Georgia State Board of Education banned Fenton's 1972 textbook on American history. ${ }^{14}$ Clearly, the new social studies movement had many opponents in Georgia. Thus, prevailing resistance to innovative curriculum, such as MACOS, with its broad examinations of culture that may have been more relevant to APS's African American students, prevented significant changes in social studies education in Atlanta.

\section{Georgia History Teacher Guides}

In addition to the controversy over MACOS and other new social studies curricula in 1975, eighth grade Georgia History was an important concern in the APS social studies curriculum. Here again, evidence demonstrates that resistance existed to employing critical pedagogies and to expanding the curriculum beyond the traditional American historical narrative. In 1983, the eighth grade social studies curriculum included two main areas: geography and cultural history. A common teacher's guide was given to all eighth grade Georgia History teachers in 1983 to "bring about a degree of standardization in the teaching of Georgia History in the Atlanta Public Schools and to assist in creating a learning experience that is meaningful, exciting, and rewarding." 15 Interestingly, the guide used words like "meaningful, exciting, and rewarding" and suggested that if teachers follow the guide their "creativity will be stimulated" and "they will motivate students to master the study of Georgia History." 16 Although, the 1983 Georgia History Teacher's Guide was intended to create a "rewarding learning experience," the objectives set forth typically fostered lower-order thinking skills. The teacher's guide suggested that students would be able to identify, recognize, or know as part, or all, of the objectives. Yet, 
the "Suggested Evaluation Procedures"17 also asked low-level questions and even suggested certain evaluations for better students compared to weaker students.

Many of the "suggested evaluation procedures" aimed at lower order thinking skills and not critical thinking. Jonathan Kozol was one of the first prominent education critics to observe and describe the prevalence of rote memorization, mindless drills, and scripted curricula in urban classrooms. ${ }^{18} \mathrm{He}$ pointed out that a disproportionate number of minority students filled special education classrooms. Many Georgia classrooms were no different from the educational practices Kozol observed nationwide. In fact, the NAACP filed suit in 1984 against thirteen Georgia school districts for discrimination against Blacks by assigning them to special education classes before testing and evaluating the students. ${ }^{19}$ True-false questions and map tests, as suggested in the APS guide, often require simple recall, rather than complex analysis. The Georgia History guide, like many social studies curricula, emphasized factual content over higher level thinking processes.

Importantly, culture and diversity were emphasized as major areas of concentration in the eighth grade Georgia History curriculum. In the 116 pages of instructional topics, approximately twenty-five pages (22 percent) specifically addressed culture and diversity. ${ }^{20}$ Out of seven units and thirty chapters, only about six chapters (20 percent) emphasized the African American impact on the history of Georgia with the focus largely on slavery. Four chapters touched on the Native American (Indian) impact on the history of Georgia. ${ }^{21}$ No evidence in the teacher's guide, however, indicated that culture and diversity were taught beyond the basics of American Indian introductions and the early impact of slavery on the state of Georgia. The recollections of several APS students suggest that many social studies teachers did not address culture and diversity in their social studies classes. ${ }^{22}$ When Norman Thomas, an African American social studies teacher 
and the Georgia Parent Teacher Association's first Black President (1985), was moved to teach in a newly integrated APS school in 1970 and began to teach a unit on Black history, he recalled that the White students were permitted to stay home. ${ }^{23} \mathrm{He}$ was grateful that he did not lose his teaching job, but he remained steadfast in his commitment to teach African American culture and history. Clearly, it took many years before the APS social studies curriculum reflected the culture and history of its student population.

Given the predominately African American student population of APS by the early 1970s, substantial significance to the contributions of African Americans, and other ethnicities, should have been more obvious. However, most of the content in the social studies Teacher's Guide placed a distinct emphasis on the European impact on the history of Georgia. Much of the social studies curriculum in the APS teacher's guides was not culturally relevant. Culturally relevant pedagogy, according to Ladson-Billings, empowers students intellectually, socially, and emotionally, by using cultural referents to impart knowledge, skills, and attitudes. ${ }^{24}$ Geneva Gay notes that using cultural knowledge, prior experiences, and frames of reference for ethnically diverse students makes learning more relevant and effective for students. ${ }^{25}$ Many APS students could not relate to the experiences of the past, because they could not see themselves in the past or as positive contributors to history. Grant states that many Black students in Georgia "believed school administrators and teachers held high-handed disregard for their beliefs and traditions." 26 Given the desegregation battle in APS and the prolonged local struggle for educational equality African American parents and students fought for, the curriculum guide's lack of emphasis on critical thinking skills and on diverse ethnic groups is salient to the study of the desegregation era social studies curriculum. 


\section{Growth of the Standards Movement in the Early 1980s}

National and local newspaper headlines in 1984 and 1985 reemphasized the importance of lower order thinking skills that were evident in the 1983 APS Teacher's Guide for eighth grade Georgia History. In particular, the newspapers depicted Geography as one of the weakest areas of school age children's knowledge. Not only did these reports of U.S. students' lack of geographical knowledge stress a need for teaching basic content, but they also emphasized the need for standardized testing. In October of 1984, the Atlanta Journal featured an article that revealed, "99 percent (a group of incoming freshman at St. Mary-of-the-Woods College) could not pick out Vietnam [on a map], 75 percent couldn't find Moscow, more than 50 percent missed Chicago, and about 9 percent couldn’t even locate Mexico."${ }^{, 27}$ The article stressed the deficiencies of U.S. students compared to students in other countries, and reiterated the need for more geography courses at the pre-college level and more testing. The tradition of questioning and inquiry promoted by MACOS in the 1970s, had lost stature, in favor of standards and testing, even in the local social studies curriculum.

In fact, by the 1980s, APS began to develop some in-depth social studies co-curricular programs to provide students with a variety of real world learning opportunities outside of the classroom. These curricular shifts reflected a stronger emphasis on providing learning opportunities in social studies that had more cultural relevance for the APS student body. Nonetheless, the textbooks remained a dominant aspect of teaching and learning social studies in many classrooms instead of opportunities offered by the co-curriculum.

\section{Atlanta Public School's Eighth Grade Social Studies Textbooks}

"Merely acknowledging a problem does not remove it. And guidelines without timetables and procedures for enforcement and monitoring will not remove bias from textbooks." ${ }^{28}$ 
In order to extend our investigation of race and the social studies curriculum, and to see how much of an impact previous findings and acknowledgements have had on racial representation in the textbooks that help shape school curriculum, we examined four social studies textbooks selected for Atlanta Public Schools that were used in classrooms in the 1970s and 1980s. All four textbooks were adopted in Georgia History eighth grade classrooms during this time period. The four textbooks include: 1) Georgia: History and Government by Albert B. Saye, 2) The Georgia History Book by Lawrence R. Hepburn, 3) A Panorama of Georgia by Louis DeVorsey, Jr., Marion Rice, Elmer Williams, and Bonnie London, and 4) Georgia: In American Society by W. B. Wingo, S. M. Terry, and R. Bussler. Each of the textbooks represents the culture, politics, history, economy, and symbols of the state of Georgia throughout their pages.

To evaluate the complexities associated with race in the social studies curriculum in Atlanta Public Schools from 1970-1990, these textbooks, when evaluated, helped reveal a more complete picture. Five common themes that reoccurred in the curriculum for nearly fifteen years were found: 1) American Indians are written out of Georgia's history after the Trail of Tears, 2) Blacks from early slavery through the twentieth century are depicted as contributors mainly through physical labor, 3) Martin Luther King, Jr. is seen as the most prominent Black person to contribute to Georgia's history, 4) the Confederacy is a way of life and lives on through the history of Georgia as it promotes White dominance over all other ethnicities, and 5) White culture is portrayed as the American way, and those who are not part of White culture have had less of an impact on the history of Georgia. 


\section{American Indians are Removed from Georgia's history After the Trail of Tears}

Several patterns are evident with respect to the portrayal of American Indians in the

Georgia history textbooks. These patterns include discussion of Indian life only in the beginning of the text, portrayal of Whites as conquerors and Native Americans as primitive, and lengthy descriptions that focus on Indian Removal. For example, Georgia: History and Government by Saye displays in a portrait on page 19, "a tribe of the Creek Indians" with an interpreter in native head dress and clothing meeting with James Oglethorpe and his men who are dressed in full uniform from head to boots. The textbook author later discusses the removal of the American Indian population by 1840 which had coexisted with the Caucasian population since the early 1700s. Shortly thereafter, the reader learns that by 1840 all Native Americans or "Indians" had been forced out of Georgia by the Indian Removal Act.

The perspective that all American Indians were removed from Georgia stands in sharp contrast with the contemporary perspective offered by the Georgia Tribe of Eastern Cherokee (a state recognized, but not federally recognized tribe), who note on their website that "The story that ALL Cherokees were removed in 1838 is a myth...even though it was a horrible event and many thousands of Cherokee died." ${ }^{29}$ According to the Tribe of Eastern Cherokee, in the early 1800s some Cherokee Indians hid in the north Georgia mountains and several mixed blood Cherokee remained in the state. The textbook author provides a second picture of the "Red" people on the "Trail of Tears" as they are forced off of their Georgia land. In this book, colors are used to designate racial categories.

Much like Georgia: History and Government by Albert Saye, The Georgia History Book also focuses only on Native American life in the beginning of the book's narrative. In contrast to the aforementioned text, Lawrence Hepburn, the author of The Georgia History Book, depicts 
Native American civilization as highly complex. Unit one is largely dedicated to sharing evidence found on how "25,000 years ago Asian people migrated from Siberia to Alaska..." and "how these people developed four traditions. ${ }^{, 30}$ The author provides considerable information to facilitate understanding of the Georgia Indians' ways of life. Detailed pictures are included to show "Pre-colonial sites" like Rock Eagle and replicas of what an Indian village may have looked like based on evidence uncovered by archaeologists. ${ }^{31}$ Not only does this textbook provide more literature and pictures to support the description of early settlements in Georgia, but the author also gives evidence of the complex and highly structured ways of life the early American Indians had.

The comprehensive narrative provides evidence of "complex trading systems, high artistic levels, social organization, and even a highly organized religious system" ${ }^{\prime 2}$ amongst the four traditions of Indians who were the early inhabitants of Georgia. While the portrayal does not emphasize primitive characteristics, the Native American culture is still viewed as foreign and ultimately problematic for the European settlers. The author describes how conflict developed between the early natives and Europeans once they arrived. "Each tribe had its own economy, government, religion, and family patterns...differing greatly from those of the Europeans... as a result, a conflict of ideas soon developed between the Indians and the whites."${ }^{\prime 33}$ This portrait is very different from Saye's textbook which gives sparse description of the lives of the natives, and to the reasons why possible conflicts may have taken place between the American Indians and early colonists. Through pictures and details in the literature, Hepburn paints a clearer picture of what took place across the Georgia lands in the 1600-1700s, and how the land developed from an area once controlled by American Indians to a land controlled by Whites. In 
the next unit, the author describes the arrival of the Europeans and how and why they inhabited Georgia lands.

Interestingly, in the first three units where European relations with natives are characterized, they are labeled as, "The Indian Problem." The author further details White culture and dominance in developing government and land, not only as an individual settlement, but also as part of what came to be the United States. White dominance and power are described through details of war with England, through the tremendous shift in the landscape of Georgia's racial makeup from American Indians to mostly Whites, and through the forced introduction of Blacks. ${ }^{34}$ Instead of describing the contributions of American Indians, the author emphasizes in great detail their removal and quickly decreasing numbers, and expresses the events as "The Indian Problem 'Solved." ${ }^{35}$ Yet Hepburn's historical perspective sharply contrasts with some of the Georgia native tribes' accounts of events surrounding the Trail of Tears. Even more curious, is the fact that the American Indian problem was "solved" and native peoples are not mentioned after the "Trail of Tears." 36

A Panorama of Georgia provides even more evidence to support the prevailing theme in the APS social studies curriculum that American Indians were written out of Georgia's history after the Trail of Tears. This story begins with "Natives and Explorers" and includes a drawing of Hernando De Soto on the very first page. De Soto is dressed in military armor, and holds his sword at the ready. He possesses a serious demeanor, one of power and honor; much like that depicted by numerous White men portrayed on most pages of the textbook. ${ }^{37}$ The De Soto image sets the tone for the rest of Georgia's history and unfolds much the same way as the other textbooks. 
Native Americans grace the early pages and very quickly encounter Europeans. "It was not until 1540 that an explorer reached the land we now know as Georgia." ${ }^{" 38}$ Interestingly, the natives in Georgia arrived "around 8,000 years ago"39 according to archaeologists; Black people arrived shortly after the first Europeans, but the history detailed in the narrative is the White man's story. In part, the emphasis on White history is due to the existence of written records that occupy an important aspect of European culture. Written records preserve accounts of who, what, when, and where that can be passed down through the generations without alteration. Oral traditions were more common amongst native people and Africans, thus making research and recorded history more difficult to construct, especially when oral traditions are lost. The way textbooks organize, display, and provide historical accounts makes it appear that one culture has been more influential; this attitude resonates and impacts how people view their worlds, who creates their worlds, and who and what is important in that world.

Most portraits of American Indians and of African Americans are recreations of descriptions written by Whites or are portraits taken by White men and preserved. Native descriptions of culture and history in early Georgia appear in the early pages, but their presence abruptly stops shortly after the War of 1812 . The history of the natives in Georgia, who occupied the Georgia lands for thousands of years, much longer than any other ethnic group, have the least coverage and recorded contributions to Georgia's history in the textbook. ${ }^{40}$

Finally, a fourth textbook by DeVorsey, Rice, Williams, and London, Georgia: In American Society, supports the evidence that demonstrates the lack of Native American representation in Georgia history books. Once the geography of Georgia is established, and the reader understands why people would want to settle in the Georgia area, the authors discuss the people who first inhabited Georgia. In "The Indians Came First," the title of chapter two, Native 
American contributions to Georgia history are described.$^{41}$ Remarkably, a picture of a current day "young Indian" is displayed with her face barely visible as she looks down to make an arrowhead. ${ }^{42}$ Yet, the textbook does not provide pictures that give individual personality to the American Indians, as no names are offered, nor are natives portrayed occupying high government positions. Most pictures display the traditional native culture, in sharp contrast with the more modern depictions of White contributions to Georgia's history.

The textbook quickly moves into the arrival of the Europeans after a very brief overview of the native culture. Immediately, European culture is depicted as the dominant culture. For example, the textbook uses "primitive" ${ }^{43}$ to describe much of the Native American culture and "dominated" $" 4$ to describe the presence of the European culture in what became the state of Georgia. Each of the visuals provided support this perspective. For example, native culture is portrayed with "primitive" characteristics: little clothing, makeshift shelter, simple weapons made by hand (bow and arrow, knives, carved utensils), elaborate religious structures to worship many gods, and very tight knit communities that provide only the basic necessities for life. ${ }^{45}$

In contrast to the American Indians, the textbook authors immediately depict the Europeans with visual evidence of dominance. The Europeans are described with words like, "explorers, conquerors, scholars, wealthy"46 that set their way of life apart from that of the American Indians, and place Europeans in a higher position. The traditional way of life displayed by natives makes their culture seem less intelligent or less advanced, and ultimately less American. The Europeans" "desire to learn and create" ${ }^{47}$ sets the tone for the rest of the textbook. The idea of expanding and spreading knowledge shows the dominant portrayal of Europeans in Georgia: In American Society. 
The description of Indian removal divides the American Indians into those who adopted the White culture and those who refused. ${ }^{48}$ The number of pictures the textbook displays of important American Indians, like important Blacks, is a very small number, and the pictures of natives or Blacks who have pictures with their names and accomplishments displayed is even less. To be exact, three pictures of American Indians with individual identities are found in Georgia: An American Society: 1) Mary Musgrove 2) Tomochichi, Chief of the Yamacraw Indians and 3) Chief Vann. These are the only pictures in the entire textbook that provide an individual personality to American Indians. While the third picture of Chief Vann is shown and named, Vann adopted White culture and wears a suit. He does not wear native clothing and seems to be posing for the picture as most White men would. The American Indians are not mentioned again after page 136, as it seems they are completely written out of Georgia history.

The portrayal of Native American culture in all four of the Georgia history textbooks gives readers the incorrect impression that natives no longer exist at all in the state. Such impressions contribute to young people's misconception that Native American culture only existed a long time ago, and is not part of contemporary society. Furthermore, all four of the textbooks portray the culture as primitive or foreign, and one that ultimately disappeared.

\section{Blacks Contributed to Georgia History Primarily through Physical Labor}

Each Georgia history textbook used in the Atlanta Public Schools characterized African American contributions by showing imagery of Blacks, from early slavery through the twentieth century, who contributed to society primarily through physical labor. According to Juanita Roderick who conducted a 1970 study, such images reinforce stereotypical negative images of Blacks, 
A review of literature and research on minority groups in textbooks, revealed that the textbook, a principal teaching source, appears to have a major role in projecting images of minority groups..., however, adult Negroes in textbooks are slighted in the respect that they are most often pictured in occupational uniform, they are not named and and they are not given speaking roles. Spanish-Americans, Orientals, European immigrants, and Indians are not treated as extensively as Negroes, and when they are considered, they appear to be cast in stereotype occupations and living quarters. ${ }^{49}$

The Georgia: History and Government textbook by Albert Saye has very limited images of Black people or other diverse racial and ethnic groups. Thus, "The Old South" unit begins on page 94, as does the depiction of Blacks as physical laborers. For example, the reader is able to view a picture labeled, "Slaves at Work." This picture shows Blacks picking cotton in a large field as they are being watched by an overseer on a horse. ${ }^{50}$ Saye notes, the "Indians were all gone," and "99.9 percent of Blacks in Georgia were slaves." "51 The text emphasizes the physical labor of Blacks and justifies the visual representations via statistics.

Not until much later in the textbook (unit ten) does the reader first encounter African Americans in pictures who appear as individuals, or as people who participate in non-labor intensive roles in society. For example, on page 170, Booker T. Washington's portrait shows him wearing a suit. This portrait of Washington appears next to Henry W. Grady and is placed chronologically after the Civil War. ${ }^{52}$ Before the Civil War, the textbook does not show any persons of color in a portrait by themselves or with a given name, but only as persons worthy of low socioeconomic and labor intensive ways of life. 
According to the textbook authors, few Black people are well-known or have made considerable contributions to the state of Georgia outside of physical labor and low wage jobs. The representation of political leadership, visually and via text, is so limited that it appears to be token. Furthermore, there are no photographs of ordinary African Americans engaged in roles such as lawyer, doctor, nurse, teacher, scientist, newspaper reporter, policeman or woman, retail salesperson, or even higher paid physical labor jobs. The textbook makes it appear that Blacks such as "Daniel A. Payne, a free Black educator, in the $1830 \mathrm{~s} ", 53$ from Charleston, South Carolina did not exist, nor any "Black men and women played critical roles in skilled occupations," ${ }^{54}$ in the South.

Hepburn's The Georgia History Book echoes the same portraiture as Georgia: History and Government. However, Hepburn's book is unique and noteworthy because the author provides many primary source documents throughout the text. For example, Heyburn includes the Laws of the Creek Nation, the Cherokee syllabary, an 1829 memorial of John Ross from representatives of the Cherokee Nation of Indians, and US President Andrew Jackson's reply. ${ }^{55}$ Unit two begins with the dominant presence of the Europeans in Georgia, and half-way through the unit the author introduces the "Black People in Georgia." 56 Interestingly, Hepburn describes all encounters separately, and provides firsthand accounts of these encounters through artifacts and oral histories. The natives occupied "Georgia" lands when the Europeans arrived, and "Blacks did not come by choice... They were brought as slaves to work for White settlers. Slavery lasted until 1865." ${ }^{, 57}$ Other sections titled, "Background on Slavery, Slavery in British America," and "A Slave's Account" describe the Black experience in early Georgia. The only visual representation is a "diagram of a slave ship... called a "slaver," which "killed thousands of Africans before they reached America. ${ }^{, 58}$ Like the American Indians, but in far fewer numbers, 
visual representations of Black people of prominent stature in the early 1600s through late 1800s to show pride, dignity, grace, or importance do not exist. The number of visuals provided to show labor intensive, low socioeconomic jobs outnumber those of prominent stature for both American Indians and African Americans throughout the textbook.

Thus, The Georgia History Book, despite the inclusion of primary source documents reflecting a range of historical perspectives, paints a mostly negative characterization of Blacks. "The Slavery Issue" is described in detail but many positive contributions of African Americans are neglected. ${ }^{59}$ Thus, readers remain unaware of Black contributions to Georgia's early history, and focus solely on their socially constructed subordinate positions to White people. Not until half-way through the textbook are contributions of Black culture illuminated. In a section labeled "Change at the Turn of the Century," Blacks still are not pictured in a positive light but in largely menial positions. For example, a picture on page 149 shows a group of Black women in a sewing class at Atlanta University. ${ }^{60}$ On page 157 a picture of "A Chain Gang" shows a Black man in prison attire with chains around his legs. Such depictions place African Americans at the bottom tiers of society. ${ }^{61}$

These images make it hard for Black students to find pride in their heritage. These negative images are reflected throughout the textbook. During the author's account of the Depression, Blacks continue to be portrayed in pictures that show low income, labor intensive jobs; for example "Chopping Cotton on Rented Land." ${ }^{62}$ Even when poor White people are shown sitting in their overcrowded apartment revealing that "eight families shared one bathroom," ${ }^{63}$ the poorest Whites still occupied a higher social strata than Blacks.

Even positive images of Blacks, beyond token political positions that appear at the end of the textbook, reveal portraits of physical ability, as demonstrated by a picture of Hank Aaron 
hitting his $715^{\text {th }}$ home run “breaking Babe Ruth's long-standing record...in Atlanta-Fulton County Stadium, April 8, 1974." "64 Although Aaron's accomplishment is certainly noteworthy, such a depiction contributes to the notion that the only respect Blacks receive in history is through physical accomplishments; indeed, they are portrayed in the majority of textbooks engaging in physical or labor intensive work as their primary contribution to Georgia's state history.

Louis DeVorsey, Jr., Marion J. Rice, Elmer Williams, and Bonnie London, begin their history of Blacks in A Panorama of Georgia similar to the other texts with a discussion of slavery and its impact on the history of Georgia. Pictures appear of Black people as slaves picking cotton by hand or working a field to grow crops. The African origins of Black people are mentioned, but no depictions of Africans in Africa are provided to portray a Black person in a position of power and dignity in comparison to the pictures provided of European explorers. Even when descriptions of post-Civil-War-era Blacks or free Black men are provided, illustrations are not included. There were free Black men who fought in the Union Army during the Civil War or who worked as abolitionists to help free many slaves in Georgia, but these images are not shown.

In the section, "A Changing Georgia" as in other textbooks, a picture of Dr. Martin Luther King, Jr appears. ${ }^{65}$ The photograph prepares the reader for the changes that will take place during this period. As the reader turns the page, to begin the section, a picture of a "moonshine still in the Georgia low country about $1880,{ }^{\prime 66}$ appears. In the photograph, a Black man dressed in old, torn work clothes stands next to a shed and moonshine jugs. Once again, the lower social status of Black people is portrayed. The hope of positive representation through the image of Dr. King was immediately taken away by displaying a moonshine still with a Black man located next 
to it. Samantha King argues, "The criminalization and pathologization of Black masculinity is so deeply inscribed and so utterly pervasive as to make..., like all Black men, always already potential criminals. ${ }^{97}$

The final textbook evaluated, Georgia: In American Society by W. B. Wingo, S. M. Terry, and R. Bussler also does not give visual representation to emphasize or minimize the portrayal of Blacks in Georgia's history. Most of the textbook was dedicated to memorializing the White history of Georgia and the White man's contributions. There are not any pictures displaying the early history of Blacks, but the authors do provide minimal representation via text and photographic images of contributions at the turn of the century. Repeated patterns and perspectives pervade all four textbooks which portray African Americans as engaged in Georgia history primarily through physical labor.

\section{Martin Luther King, Jr. is Seen as the Most Prominent African American to Contribute to Georgia's History}

The author of Georgia: History and Government begins representing Blacks as more prominent contributors to Georgia's history in unit ten. This unit allows the reader to encounter African Americans in pictures that represent them as individuals and not as groups of people. Saye does not show any persons of color in a portrait by themselves or with a given name before the Civil War. Most group pictures of Black people depict how African Americans have made progress in a world of adversity and inequality by describing or portraying Civil Rights leaders, such as Martin Luther King, Jr. (p. 219), Andrew Young (p. 239), and Senator Leroy Johnson (p. 239). ${ }^{68}$ No pictures or examples of Georgians of color who meet the positive public awareness for something other than political leadership are presented. The sparse existence of these visuals make these depictions seem token-like. The textbook could have easily depicted Benjamin 
Banneker as one of the many well accomplished Black people who made a significant impact on history. He "published six almanacs, for the years 1792 to 1797, in twenty-eight editions, printed in Baltimore, Philadelphia, Petersburg, Richmond, Wilmington, and Trenton." ${ }^{99}$

The Georgia History Book emphasizes the prevailing theme that Martin Luther King, Jr. (MLK, Jr.) was the most prominent Black person to contribute to Georgia's history. Immediately, Hepburn emphasizes this idea as it displays MLK, Jr. as the lone portrait of an African American of the ten visuals displayed on the cover. This portrait may lead the reader to think that possibly no other people of color besides Martin Luther King, Jr. have contributed in an important way to the history of Georgia. On page 196 Dr. King is shown "on the steps of his boyhood home in Atlanta. ${ }^{, 70}$ Surprisingly, the textbook ends on page 207. Not until page 198, after MLK, Jr. is presented as a prominent figure, does a picture of Andrew Young appear. The caption on the picture reads, "After serving in the U.S. Congress and as U.S. Ambassador to the United Nations, Andrew Young became mayor of Atlanta in 1982."1ㅣ This caption provides evidence that Black people held prominent positions in society, but this acknowledgement comes at the very end of the textbook. Many history teachers have difficulty completing the curriculum and often contemporary history is neglected or rushed at the end of the semester, thus leaving little time to discuss content at the end of textbook.

A Panorama of Georgia opens its section, "A Changing Georgia" with a portrait of Dr. Martin Luther King, $\mathrm{Jr}^{72}$ There is not any text, caption, or words to describe the meaning of the prominent and domineering, larger than life visual. The title of the section says it all, he was and is the symbol of the contributions of Black people to Georgia's history. No other visuals compete or come close to giving credit to other prominent Black people in this textbook. A Panorama of Georgia, also expounds upon Martin Luther King, Jr.'s contributions. 
The first picture of a prominent Black person in Georgia: In American Society is of Booker T. Washington, and the caption notes he "began Tuskegee Institute to teach young Blacks a trade." ${ }^{, 73}$ Along with Booker T. Washington's contributions, purposefully setting the history of Blacks apart from White history, the textbook also mentions W. E. B. DuBois, but does not provide a visual image, and after briefly mentioning these two leaders, the textbook dismisses Black history quickly, and immediately returns to the familiar narrative of White history. No other ethnic groups are recognized as important until page 246 when Dr. Martin Luther King, Jr. is noted for contributions to Georgia's history for two reasons: 1) "his impact on the social and political change that has occurred in the state," and 2) "King was born in Georgia in 1929." "74 Georgia: In American Society, dedicates three pages to the contributions of Dr. Martin Luther King, Jr. After the textbook addresses Dr. King as the most prominent Black figure in the state's history, the only other picture that appears of someone who is not White in Georgia is of Mayor Andrew Young. Mayor Young appears in a picture on page 271 with a brief caption, but there is no reference to him in the narrative content. Thus, readers of the four Georgia history textbooks likely are given the impression that MLK, Jr. is the most prominent, if not the only African American contributor to Georgia history.

\section{The Confederacy is a Way of Life and Lives on through the History of Georgia}

All of the textbooks, including Georgia: History and Government, extend the idea that the Confederacy is a way of life and lives on through the history of Georgia and promotes White dominance over all other ethnicities. The first noticeable symbol recognizing the Confederacy and White dominance is displayed on the front cover of Georgia: History and Government- the old Georgia state flag. The flag is set apart from the rest of the textbook cover. The flag is small, 
but beams with bright blue and red. On the right side of the flag is the familiar cross (X) of the Confederacy, commonly known as the rebel flag, and to its left, on about one quarter of the rectangular space, is the state seal. The state flag is located at the top left of the front cover, and is easily seen because it greatly contrasts with the subdued brown background with lightly scattered state seals. Unlike Georgia: History and Government, The Georgia History Book does not display the Confederacy as a way of life and Whites as the dominant culture, but the textbook emphasizes the events leading up to the Civil War, events during the Civil War, prominent figures of the Civil War, and the impact to Georgia after the Civil War. The discussion of the Civil War stands in sharp contrast to other events addressed in The Georgia History Book. A Panorama of Georgia does not have the symbols of the Confederacy on the front cover and does not immediately draw unwarranted attention. The cover includes subtle pictures that depict the economy of Georgia: tourism, textiles, timber, shipping, manufacturing, and sports, but the pictures the authors choose to represent these areas are dominated by people with disposable income who engage in golf, horseback riding on Georgia's coast, rafting, and other leisure activities. Unlike the subtlety of the pictures on the front cover, the back cover has a picture of the United States flag flying above the state flag. Both are proudly displayed on a flag pole. The Confederate rebel flag symbol which was part of the 1980s state flag graces the back cover. This symbol of the Confederacy was a prominent component of the state flag into the early twenty-first century.

Georgia: In American Society also supports the undying way of life and White dominance in the Confederacy as the cover is boldly decorated with the Georgia flag displaying, once again, the stars and bars of the Confederacy. Several of the textbooks include descriptions of southern Civil War heroes, the Lost Cause, and Civil War depictions in books and movies, 
such as Gone With the Wind. The cover of the book has the colors and stars and stripes of the U.S. flag to show the thirteen original colonies and the crossed bars to show the dedication to the Confederacy, alongside the state seal. The cover overtly illustrates dedication to the South and the Southern way of life. Thus, all four textbooks establish and focus on the Civil War and the Confederacy. In the South, in many respects, the Civil War is not only part of the past but lives on in the present.

\section{White Culture is Seen as the American Way}

Georgia: History and Government interestingly describes the "varied" makeup of Georgia's people. The "White" people are described from the top of page 20 to the bottom of page 21; the "Red" and "Black" people share page $22 .{ }^{75}$ The textbook displays only one picture throughout its first ninety-three pages and first three units of a person of Georgia's "varied" makeup other than White people. This characterization painting the White culture as the American way, does not shift at any point to show change over time in the racial makeup of the state or the racial representation in Georgia's politics, government, economy, education, or leisure. However, this textbook does display the oppressive nature of existence that people of color have experienced in Georgia. Yet, according to the authors, only a hand full of Black people or Native American are well-known or have made considerable contributions to the state. Furthermore, few representations in this text show groups of African American or Native American people in prominent roles.

Georgia: History and Government does provide "honorable mentions" to other ethnic groups. For example, a picture of a Cambodian girl appears on page 201. The girl's family is

compared to "the settlers of 1733 , they came looking for a new start in life, a new opportunity.""76 The literature provided paints these modern day settlers in a subordinate position to White 
people. A "hero like" status is attributed to these immigrants in the section, "A Chance for a Better Life" as they settle in Georgia "on charity", and "learn English while older family members find jobs."77

All four of the textbooks' depictions are recorded from a Eurocentric perspective. For example, many more pictures of prominent White men, such as Joseph S. Pemberton, Governor Joe Frank Harris, President Franklin D. Roosevelt, and President Jimmy Carter, appear in pictures throughout the text and display their prominence in Georgia's history and in national history. These men are shown as dignified, honorable, reputable, and of high social class, unlike most of the small number of pictures displayed of natives, Blacks, or other ethnicities.

Even White women do not appear until the later third of the texts. For example, Margaret Mitchell and Martha Berry are examples of White women who are portrayed. The text adjacent to their photographs reads, "the period between the two World Wars was one in which Georgia women played an increasing number of roles." 78 Apparently, women's contributions in Georgia only became important during the early twentieth century. A few prominent Black women are portrayed in the last third of the book. Charlayne Hunter is seen in a photograph, obviously taken from a distance, as she walks the campus of The University of Georgia. ${ }^{79}$ Her face is barely visible, unlike the faces of the White women who appeared in previous pages. Ms. Hunter does not appear in the photo alone, but surrounded by a crowd of people. The reader then encounters the second photo of a prominent Black woman, two pages later, as the authors present a section on "Civil Rights in Georgia." A photo of Coretta Scott King is labeled as, "President of the Martin Luther King, Jr. Center." ${ }^{80}$ This photograph of Coretta Scott King is the only photograph of a solitary Black woman appearing in the entire 301 pages of A Panorama of Georgia; it is the only picture of a Black woman that offers individual personality to Black women. The depiction 
of Coretta Scott King is more than likely due to the overt dedication in all Georgia history textbooks to Dr. Martin Luther King, Jr.'s role as the most recognized Black individual in Georgia’s history.

After reviewing DeVorsey, Rice, Williams, and London's A Panorama of Georgia and the other textbooks, several questions arise. Did very few Black people contribute to Georgia's history? Did Native Americans cease to exist in Georgia? Did only a few Blacks and women contribute to the state history? Were most contributions to Georgia's history made by White men? Other ethnic groups appear in the later history of Georgia, as the reader is introduced to pictures of Asians coming to Georgia because of the economy and the impact of businesses locating in Georgia in the twentieth century. These textbooks seem to only recognize other ethnic group contributions to recent history. The authors provide a picture of Asian men at "Macon's Cherry Blossom Festival." ${ }^{81}$ No names or recognition of the men are offered, nor do the authors give an explanation as to why these men are in Georgia experiencing the festival. The lack of characterization is also true for a picture of Asian men surrounding "Atlanta Mayor Andrew Young and City Council President Arrington during a trip overseas." ${ }^{92}$ With both pictures, the authors do not explain who the Asian men are or their contributions to society.

The authors describe at length in A Panorama of Georgia what Georgia has to offer, and suggests that it is a result of the dedication and hard work of White men. The textbook shows in its final pages how the White man's contributions and implementations of government, economy, and politics have made Georgia a "desirable" place for living, working, and business.

"It is easy to see why Georgia is seen as a desirable location for new business." ${ }^{\prime 3}$ With little interest in what other ethnic groups offer to the history of Georgia, the reader is left with 
questions about why the White history of Georgia is the most recognized and personalized.

\section{Conclusion}

The four eighth grade Georgia history textbooks reviewed in this chapter are just a snapshot of how race was portrayed in social studies education during the desegregation era. Common themes emerged in each textbook including the ideas that: 1) American Indians are written out of Georgia's history after the Trail of Tears, 2) Blacks are contributors of mainly physical labor depicted from early slavery through the twentieth century, 3) Martin Luther King, Jr. is seen as the most prominent Black person to contribute to Georgia's history, 4) the Confederacy is a way of life and lives on through the history of Georgia as it promotes White dominance over all other ethnicities, and 5) White culture is seen as the American way, and those who are not part of White culture have had less of an impact on the history of Georgia. All four textbooks support the common concept that traditional history curriculum means White history because White history is the primary narrative that is described. Contrast the stories of Georgia history in the four textbooks with a non-traditional curriculum or non-Western curriculum such as MACOS that was offered in the early 1970s. Inquiry-based learning curricula, such as MACOS, offered opportunities to learn about less familiar non-Western cultures. However, several factors, including political opposition, led to the demise of MACOS and other new social studies curricula. In order to keep the White culture in power, however, the White narrative must be prominent in the history taught in public schools; it must be common across boundaries, and it must have common themes across centuries and history.

Nothing handed down from the past could keep race alive if we did not constantly reinvent and re-ritualize it to fit our own terrain. If race lives on today, it can do so only because we continue to create and recreate it 
in our social life, continue to verify it, and thus continue to need a social vocabulary that will allow us to make sense, not of what our ancestors did then, but what we choose to do now. ${ }^{84}$

The question of how race featured in the eighth grade Georgia History curriculum cannot be simply or singularly answered. Context, teacher, student, and textbook all mattered and impacted the kinds of learning that occurred in the classrooms. Nonetheless, the glimpse that is offered from the archival materials, the interviews with students and teachers, and the four textbooks, reveals missed opportunities for inquiry-based curricula in favor of a traditional, familiar narratives of European progress and success.

\footnotetext{
EndNotes:

${ }^{1}$ C. H. Bohan \& P. Randolph, “The Social Studies Curriculum in Atlanta Public Schools During the Desegregation Era," Theory and Research in Social Education 37, no.4 (2009): 543-569.

${ }^{2}$ W. J. Urban, \& J. L. Wagoner, Jr., “American Education: A History,” New York: McGraw Hill, 2004.

${ }^{3}$ T. Fallace, "Did the Social Studies Really Replace History in American Secondary Schools?" Teachers College Record 110, no. 10 (2000): 2245-2270; M. B. Lybarger, "The Historiography of Social Studies: Retrospect, Circumspect, and Prospect," In J.P. Shaver (Ed.). Handbook of Research on Social Studies Teaching and Learning (pp. 3-15). (New York: Macmillan Publishing, 1991); E. W. Ross, "The Social Studies Curriculum: Purposes, Problems, and Possibilities," (State University of New York Press, 1997); Thornton, S. Teaching Social Studies that Matters: Curriculum for Active Learning. (New York: Teachers College Press, 2005).

${ }^{4}$ B. S. Stern (Ed.), "The New Social Studies: People, Programs, Politics and Perspectives. (Charlotte, NC: Information Age, 2009).

${ }^{5}$ J. B. Moon, Coordinator of Social Science. Memorandum: Re: Man: A Course of Study. (Retrieved October 21, 2008 from the Atlanta Public School Archives: File Cabinet S, Folder Social Studies/Sciences, 1975).

${ }^{6}$ B.S. Stern, "The New Social Studies."

7 J. S. Bruner, "Toward a Theory of Instruction," (Cambridge, MA: Belkapp Press, 1966). J. S. Bruner, "In Search of Mind: Essays in Autobiography," ( New York: Harper \& Row, 1983). J. S. Bruner, "The Culture of Education. (Boston: Harvard University Press, 1996).

${ }^{8}$ J.S. Bruner, "The Culture of Education,” (Boston: Harvard University Press, 1996).

${ }^{9}$ G. T. Lappan, “The MACOS Materials: How Success Can Go Awry. In Reflecting on Sputnik: Linking the Past, Present, and Future Educational Reform, Symposium, (Conducted by the Center for Science, Mathematics and Engineering Education. Retrieved March 2, 2008, from http://www.nas.edu/sputnik/lappan3.htm, October, 1997).

${ }^{10}$ C. Quinn, "Baptist Population Plummets in Georgia," The Atlanta Journal Constitution. Retrieved March 2, 2009 from http://www.ajc.com/metro/content/metro/stories/2008/05/15/decline 0515.html, May 15, 2008.

${ }^{11}$ J. J. Kilpatrick, "A Teacher's View of MACOS," The Atlanta Constitution, 4A, (April 24, 1975).

${ }^{12}$ S. Smith, "An Oral History Interview with Susan Smith, Northside High School graduate/Interviewer Chara Haeussler Bohan,” Georgia State University, College of Education, Atlanta, GA. (May 11, 2007).
} 
${ }^{13}$ Shaftel, F. (1968). Review of The New Social Studies. Teachers College Record, 69(7), 618.

${ }^{14}$ Georgia history textbooks. The new Georgia encyclopedia. Retrieved July 19, 2007, from

www.georgiaencyclopedia.org/nge/Article.jsp?id=n-859 (n.d.).

${ }^{15}$ Atlanta Public Schools. . Georgia History teacher's Guide: Eighth grade. Social Science Papers, Atlanta Public School Archives, Atlanta, GA, (1983).

${ }^{16}$ Atlanta Public Schools. Georgia History Teacher's Guide: Eighth grade. Social Science Papers, (Atlanta Public School Archives, Atlanta, GA, 1983), ii.

${ }^{17}$ Atlanta Public Schools. Georgia History Teacher's Guide: Eighth grade. Social Science Papers, (Atlanta Public School Archives, Atlanta, GA. "Suggested Evaluation Procedures," 1983), 10.

${ }^{18}$ Kozol, J. "Savage Inequalities: Children in America’s Schools," (New York: Crown Publishers, Inc, 1991);

J. Kozol. "The Shame of the Nation: The Restoration of Apartheid Schooling in America." (New York: Crown Publishers, 2005).

${ }^{19}$ D. S. Grant, "The Way It Was in the South: The Black Experience in Georgia," (Athens: The University of Georgia Press, 1993).

${ }^{20}$ Atlanta Public Schools. Georgia History Teacher's Guide: Eighth grade. Social Science Papers, (Atlanta Public School Archives, Atlanta, GA, 1983), iii-iv.

${ }^{21}$ Atlanta Public Schools. (1983). Georgia History Teacher's Guide: Eighth grade. Social Science Papers, (Atlanta Public School Archives, Atlanta, GA, 1983) , iii-iv.

${ }^{22}$ J. Doe, An Oral History interview with Jane Doe, Henry W. Grady High School graduate/Interviewer: Chara Haeussler Bohan. Georgia State University, College of Education, Atlanta, (February 13, 2008). S. Smith, An oral history interview with Susan Smith, Northside High School graduate/Interviewer Chara Haeussler Bohan. Georgia State University, College of Education, Atlanta (May $11,2007)$.

${ }^{23}$ N. Thomas, An Oral History interview with Dr. Norman Thomas, Atlanta Public Schools Social Studies Teacher, 1966-1973, Community Relations Coordinator under Dr. Alonzo Crim, 1973-1988/Interviewer: Patricia Randolph. (Georgia State University, College of Education, Atlanta (January 15, 2009).

${ }^{24}$ G. Ladson-Billings, "The Dreamkeepers: Successful Teachers of African American Children," (San Francisco: Jossey-Bass, 1994).

${ }^{25}$ G. Gay, "Culturally Responsive Teaching," (New York: Teachers College Press, 2000).

${ }^{26}$ D. S. Grant, "The Way It Was in the South: The Black Experience in Georgia," (Athens: The University of Georgia Press, 1993), 530.

${ }^{27}$ United Press International, "Students Need to Learn Geography, Teachers Say," The Atlanta Journal, (October 29, 1984), 5-B.

${ }^{28}$ G. E. Britton, \& M. C. Lumpkin, "Subliminal Bias in Textbooks," The Reading Teacher, 31, 1 (October, 1977), 40- 45.

29 "GeorgiaTribe of Eastern Cherokee," copyright 2003-2010, accessed October 11, 2010,

http://www.georgiatribeofeasterncherokee.com.

${ }^{30}$ Lawrence R. Hepburn, "The Georgia History Book," (Athens, GA: Institute of Government, University of Georgia,1982), 9.

${ }^{31}$ Lawrence R. Hepburn, "The Georgia History Book," 11.

${ }^{32}$ Lawrence R. Hepburn, "The Georgia History Book," 9-12.

${ }^{33}$ Lawrence R. Hepburn, "The Georgia History Book," 13.

${ }^{34}$ Lawrence R. Hepburn, "The Georgia History Book," 41-144.

${ }^{35}$ Lawrence R. Hepburn, "The Georgia History Book," 76-86.

${ }^{36}$ Lawrence R. Hepburn, "The Georgia History Book," 86.

${ }^{37}$ L. DeVorsey, Jr., M. J. Rice, E. Williams, \& B. London, “A Panorama of Georgia," 19.

${ }^{38}$ L. DeVorsey, Jr., M. J. Rice, E. Williams, \& B. London, “A Panorama of Georgia," 25.

${ }^{39}$ L. DeVorsey, Jr., M. J. Rice, E. Williams, \& B. London, “A Panorama of Georgia," 22.

${ }^{40}$ L. DeVorsey, Jr., M. J. Rice, E. Williams, \& B. London, "A Panorama of Georgia," 22-35, 49-63.

${ }^{41}$ W. B. Wingo, S. M. Terry, \& R. Bussler, "Georgia: In American Society," 19-33.

${ }^{42}$ W. B. Wingo, S. M. Terry, \& R. Bussler, "Georgia: In American Society," 20.

${ }^{43}$ W. B. Wingo, S. M. Terry, \& R. Bussler, "Georgia: In American Society," 30.

${ }^{44}$ W. B. Wingo, S. M. Terry, \& R. Bussler, "Georgia: In American Society," 38.

${ }^{45}$ W. B. Wingo, S. M. Terry, \& R. Bussler, "Georgia: In American Society," 19-33.

${ }^{46}$ W. B. Wingo, S. M. Terry, \& R. Bussler, "Georgia: In American Society," 36-39.

${ }^{47}$ W. B. Wingo, S. M. Terry, \& R. Bussler, "Georgia: In American Society," 38.

${ }^{48}$ W. B. Wingo, S. M. Terry, \& R. Bussler, "Georgia: In American Society," 126-135.

49 J. Roderick, "Improving College and University Teaching," (Teaching Goals and Strategy, 18, 2, (Spring, 1970), 129-132.

${ }^{50}$ Albert B. Saye, "Georgia: History and Government," 94.

${ }^{51}$ Albert B. Saye, "Georgia: History and Government," 95.

${ }_{52}$ Albert B. Saye, "Georgia: History and Government," 170.

${ }^{61}$ Lawrence R. Hepburn, "The Georgia History Book," 157.

${ }^{62}$ Lawrence R. Hepburn, "The Georgia History Book," 173. 
${ }^{63}$ Lawrence R. Hepburn, “The Georgia History Book,” 172.

${ }^{64}$ Lawrence R. Hepburn, "The Georgia History Book," 205.

${ }^{65}$ L. DeVorsey, Jr., M. J. Rice, E. Williams, \& B. London, “A Panorama of Georgia,” 195.

${ }^{66}$ L. DeVorsey, Jr., M. J. Rice, E. Williams, \& B. London, “A Panorama of Georgia," 202.

${ }^{67}$ S. King, "How To Be Good: The NFL, Corporate Philanthropy, and The Racialization of Generosity. In Race, Identity, and Representation in Education, Edited by C. McCarthy, et al, (New York: Routledge, 2005), 273-286,

${ }^{68}$ Albert B. Saye, "Georgia: History and Government," 219 \& 239.

${ }^{69}$ S. Kaplan, \& E. N. Kaplan, "The Black Presence in the Era of the American Revolution," (Amherst, MA: The University of Massachusetts Press, 1989), 137.

${ }^{70}$ Lawrence R. Hepburn, “The Georgia History Book,” 196.

${ }^{71}$ Lawrence R. Hepburn, "The Georgia History Book," 198.

${ }^{72}$ L. DeVorsey, Jr., M. J. Rice, E. Williams, \& B. London, “A Panorama of Georgia,” 195.

${ }^{73}$ W. B. Wingo, S. M. Terry, \& R. Bussler, "Georgia: In American Society," 215.

${ }^{74}$ W. B. Wingo, S. M. Terry, \& R. Bussler, "Georgia: In American Society," 246.

${ }^{75}$ Albert B. Saye, "Georgia: History and Government," 20-22.

${ }^{76}$ Lawrence R. Hepburn, "The Georgia History Book," 201.

${ }^{77}$ Lawrence R. Hepburn, "The Georgia History Book," 201.

${ }^{78}$ L. DeVorsey, Jr., M. J. Rice, E. Williams, \& B. London, “A Panorama of Georgia,” 204.

${ }^{79}$ L. DeVorsey, Jr., M. J. Rice, E. Williams, \& B. London, “A Panorama of Georgia," 216.

${ }^{80}$ L. DeVorsey, Jr., M. J. Rice, E. Williams, \& B. London, “A Panorama of Georgia,” 218.

${ }^{81}$ L. DeVorsey, Jr., M. J. Rice, E. Williams, \& B. London, "A Panorama of Georgia," 248.

${ }^{82}$ L. DeVorsey, Jr., M. J. Rice, E. Williams, \& B. London, "A Panorama of Georgia," 300.

${ }^{83}$ L. DeVorsey, Jr., M. J. Rice, E. Williams, \& B. London, "A Panorama of Georgia," 250.

${ }^{84}$ B. Fields, "Slavery, Race, and Ideology in the United States of America," New Left Review (May/June, 1990), 118. 